\title{
Penggunaan Sumber Belajar Berbasis Information Technologi dalam Meningkatkan Hasil Belajar Siswa Pelajaran IPS di Kelas VIII MTs Nuris Silo
}

\author{
This Study Examines the Use of Information Technology-Based \\ Learning Resources, Abbreviated as IT, in Improving Student \\ Learning Outcomes in Social Studies Class VIII at MTs Nuris Silo
}

\author{
Fikriatul Hasanah' \\ ${ }^{1}$ MTs Nurul Islam Silo
}

\begin{tabular}{l} 
INFORMASI ARTIKEL \\
\hline Diterima: 29 September 2021 \\
Direvisi: 29 Desember 2021 \\
Publikasi Online: \\
31 Desember 2021 \\
KATA KUNCI
\end{tabular}

sumber belajar, information technology, hasil belajar

\begin{abstract}
The use of learning resources in the teaching and learning process is very necessary for both teachers and students. Learning resources are all kinds of sources that exist outside of students whose existence facilitates the learning process. Information technology is defined as science in the field of computer-based information and its development is very rapid. In the world of education, the existence of information technology as a medium is very necessary. Teachers can use learning resources obtained from the internet in the form of ebooks, journals and others so that students' insights can be broadened. MTs Nuris Silo in the learning process, the teacher uses Information Technology-based learning resources in Social Studies Subjects for class VIII, namely the teacher uses student books in the form of ebooks, uses videos, articles from the internet, and pictures. The results of the use of technology-based learning resources can facilitate the learning process. students understand what is explained by the teacher from those who do not know to know, from those who do not understand to understand. Learning outcomes are an important aspect for educators, because by assessing student learning outcomes, educators obtain information about student learning progress. This has been proven by the results of the assignments given by the teacher.
\end{abstract}




\section{A B S T R A K}

Penelitian ini mengkaji tentang penggunaan sumber belajar berbasis Information Technologi yang disingkat IT dalam meningkatkan hasil belajar siswa pada pelajaraan IPS kelas VIII di MTs Nuris Silo. Penggunaan sumber belajar dalam proses belajar mengajar sangat diperlukan baik guru maupun siswa. Sumber belajar (learning resources) adalah segala macam sumber yang ada di luar diri siswa yang keberadaannya memudahkan terjadinya proses belajar. Teknologi informasi diartikan diartikan sebagai ilmu pengetahuan dalam bidang informasi yang berbasis komputer dan perkembanganya sangat pesat. Dalam dunia pendidikan adanya teknologi informasi sebagai media sangat diperlukan. Guru dapat menggunakan sumber belajar yang didapat dari internet berupa ebook, jurnal dan lain-lain supaya wawasan siswa dapat bertambah luas. MTs Nuris Silo dalam proses belajar guru menggunakan sumber belajar berbasis Information Technologi pada Mata Pelajaran IPS kelas VIII yaitu guru menggunakan buku siswa dalam bentuk ebook, penggunaan video, artikel-artikel dari internet, dan gambar. Hasil dari penggunaan sumber belajar yang berbasis teknologi tersebut dapat mempermudah proses pembelajaran. siswa memahami apa yang dijelaskan oleh guru dari yang tidak tahu menjadi tahu, dari yang tidak mengerti menjadi mengerti. Hasil belajar merupakan aspek yang penting bagi bagi pendidik, karena dengan penilaian hasil belajar siswa pendidik memperoleh informasi tentang kemajuan belajar siswa. Hal tesebut telah dibuktikan dengan hasil tugas yang diberikan oleh guru.

\section{Pendahuluan}

Pembelajaran pada hakikatnya adalah suatu proses, yaitu proses mengatur, mengorganisasi lingkungan yang ada di sekitar peserta didik sehingga dapat menumbuhkan dan mendorong peserta didik melakukan proses belajar dan pembelajaran juga dikatakan sebagai proses memberikan bimbingan atau bantuan kepada peserta didik dalam melakukan proses belajar (Pane and Darwis Dasopang 2017). IPS merupakan salah satu mata pelajaran yang diberikan di sekolah untuk mengkaji seperangkat peristiwa, fakta, konsep, dan generalisasi yang berkaitan dengan isu-isu sosial.

Tujuan adanya mata pelajaran IPS adalah mengembangkan potensi peserta didik agar peka terhadap masalah sosial yang terjadi di masyarakat, memiliki sikap mental positif 146 Heritage: Journal of Social Studies | Vol 2, No , Desember 2021 https://doi.org/10.xxxx/xxxx. 
terhadap perbaikan segala ketimpangan yang terjadi, dan terampil mengatasi setiap masalah yang terjadi sehari-hari baik yang menimpa dirinya sendiri maupun yang menimpa kehidupan masyaraka (Pane and Darwis Dasopang 2017).

Penggunaan model dan metode yang sesuai dengan materi pembelajaran tidak bisa dipisahkan dengan yang namanya sumber belajar. Menurut Donald P. Ely sumber belajar adalah data, orang, dan atau sesuatu yang memungkinkan peserta didik melakukan belajar (Warsita 2009).

Sumber belajar dapat meningkatkan hasil belajar siswa, dengan demikian diperlukan sumber belajar yang dapat menyesuaikan dengan keadaan siswa sehingga proses pembelajaran berjalan dengan baik. Maka dari itu dengan penggunakan sumber belajar berbasis information technologi sangat diperukan, seperti computer, LCD Proyekter, internet, dan power point. Interaksi antara guru dan siswa tidak hanya dilakukan melalui hubungan tatap muka tetapi juga dilakukan dengan menggunakan media-media tersebut.

Penerapan penggunaan sumber belajar di MTs Nurul Islam Silo pembelajaran IPS. Ketika pembelajaran berlangsung guru cenderung menggunakan teknologi yang tersedia disekolah sebagai sumber belajar. Sumber belajar yang berbasis teknologi seperti artikelartikel yang ada di internet dikembangkan oleh guru sebagai sumber belajar siswa supaya ilmu yang didapatkan tidak hanya dari buku siswa. Guru mata pelajaran IPS mengarahkan siswa-siswi dalam mencari artikel-artikel tersebut menggunakan laptop dan komputer yang ada di sekolah maupun milik siswa sendiri dengan adanya fasilitas wifi yang disediakan oleh pihak sekolah.

\section{Metode}

Penentuan informan menggunakan purposive. Teknik pengumpulan data yang digunakan menggunakan wawancara, observasi, dan dokumentasi. Analisis data yang digunakan analisis interaktif Miles and Huberman yang meliputi pengumpulan data, kondensasi data, penyajian data, dan penarikan kesimpulan dan verifikasi. Untuk menguji keabsahan data menggunakan triangulasi sumber.

\section{Hasil \& Diskusi}

Penggunaan model dan metode yang sesuai dengan materi pembelajaran tidak bisa dipisahkan dengan yang namanya sumber belajar. Menurut Donald P. Ely sumber belajar adalah data, orang, dan atau sesuatu yang memungkinkan peserta didik melakukan belajar (Warsita 2009). Penggunaan sumber belajar berbasis information technologi pada Mata 
Pelajaran IPS di MTs Nurul Islam Silo yaitu guru menggunakan buku siswa dalam bentuk ebook, video, artikel-artikel dari internet, dan gambar. Ada beberapa ciri-ciri dalam penggunaan sumber belajar, yaitu sumber belajar harus mampu memberikan kekuatan dalam proses belajar mengajar, sehingga tujuan pembelajaran dapat tercapai secara maksimal, sumber belajar harus mempunyai nilai-nilai instructional edukatif, yang dapat mengubah dan membawa perubahan yang sempurna terhadap tingkah laku sesuai dengan tujuan yang ada, dengan adanya klasifikasi maka sumber belajar yang dimanfaatkan (mempunyai ciri-ciri tidak terorganisasi dan tidak sistematis baik dalam bentuk maupun isi, tidak mempunyai tujuan pembelajaran yang eksplisit, hanya dipergunakan untuk keadaan tertentu atau secara incidental, dan dapat dipergunakan untuk tujuan pembelajaran), sumber belajar yang dirancang (resources by designed) mempunyai ciri-ciri yang spesifik sesuai dengan tersedianya media, dan sumber belajar dapat digunakan secara sendirisendiri (terpisah), tetapi juga dapat digunakan secara kombinasi(gabungan) (Rohani 1997).

Era 4.0 dimana teknologi semakin canggih dan mudah dalam mengakses pengetahuan sebagai tabahan wawasan dan dijadikan sebagai sumber belajar. Penggunaan sumber belajar yang berbasis teknologi tersebut dapat mempermudah proses pembelajaran. Siswa memahami apa yang dijelaskan oleh guru dari yang tidak tahu menjadi tahu, dari yang tidak mengerti menjadi mengerti. Hal ini berkaitan dengan teori yang mengatakan bahwa sumber Sumber belajar (learning resources) adalah segala macam sumber yang ada di luar diri siswa yang keberadaannya memudahkan terjadinya proses belajar (Musfiqom 2012).

Siswa menikmati proses pembelajaran dengan penggunaan sumber belajar berbasis teknologi tersebut dalam suasana belajar yang kondusif. Penggunaan sumber belajar seperti video dapat mendorong semangat belajar yang tinggi karena siswa dapat melihat langsung meskipun melalui pemutaran video. Fasilitas yang tersedia di sekolah seperti, wifi, computer, LCD, dan proyektor sangat mendukung penggunaan sumber belajar berbasis Information Technologi untuk meningkatkan hasil belajar IPS di Madrasah. Selain fasilitas tersebut siswa membawa nootbook ke dalam kelas. Dengan adanya fasilitas yang tersedia di Madrasah dan juga milik siswa tersebut saat proses belajar berlangsung siswa diarahkan untuk browshing materi yang berkaitan dengan tema yang diajarkan oleh guru dan hasil dari browshing tersebut dapat memperluas pengetahuan siswa terkait materi IPS dan juga ilmu yang diperoleh tidak hanya dari guru melainkan dapat dari sumber yang lain.

Selain hal tersebut penggunaan sumber belajar berbasis information technologi juga didukung dengan teori sumber belajar menurut AECT (Association of Education 
Communication Technology) bahwa "klasifikasikan sumber belajar, seperti Message (pesan), yaitu informasi atau ajaran yang diteruskan oleh komponen lain dalam bentuk gagasan, fakta, arti dan data. Termasuk dalam komponen pesan adalah semua bidang studi atau mata kuliah atau bahan pengajaran yang diajarkan kepada peserta didik, people (orang), yaitu manusia yang bertindak sebagai penyimpan, pengolah, dan penyaji pesan (termasuk kelompok ini adalah guru, dosen, tutor, dan peserta didik), materials (bahan), yaitu perangkat lunak yang mengandung pesan untuk disajikan melalui penggunaan alat atau perangkat keras ataupun oleh dirinya sendiri. Berbagai program media termasuk kategori materials seperti transparansi, slide, film, video, modul, majalah, dan buku, web (internet), device (alat), yaitu sesuatu (perangkat keras) yang digunakan untuk menyampaikan pesan yang tersimpan dalam bahan. Misalnya: overhead projector, slide, video, tape recorder, radio, dan televise, technique (teknik), yaitu prosedur yang dipersiapkan untuk penggunaan bahan, peralatan, orang, dnn lingkungan untuk menyampaiknn pesan. Misalnya: pengajaran berprogram, simulasi demonstrasi, tanya jawab, dan CBSA, dan setting (lingkungan), yaitu situasi atau suasana sekitar di mana pesan disampaikan, baik lingkungan fisik seperti ruang kelas, perpustakaan, aboratorium, taman, lapangan, maupun lingkungan non fisik misalnya suasana belajar itu sendiri: tenang, ramai, dan lelah (Umam 2018).

Hasil belajar siswa dalam pembelajaran IPS merupakan salah satu bentuk konkrit dalam menentukan keberhasilan dalam sebuah pembelajaran. Hal ini juga berkaitan dengan teori yang mengatakan bahwa Output peserta didik yang dihasilkan dari proses pembelajaran dapat digolongkan ke dalam tiga ranah berdasarkan Taksonomi Bloom, yaitu ranah kognitif, psikomotorik, dan afektif (Rusman 2012).

Guru, harus melakukan tes baik berupa tugas kelompok maupun tugas mandiri untuk mengetahui sejauh mana perubahan hasil belajar siswa dengan menggunakan sumber belajar berbasis teknologi informasi seperti, Ebook buku siswa, artikel, dan video.

Pemberian tugas-tugas yang dilakukan oleh siswa terdapat hasil belajar yang menjadi tolak ukur dalam menentukan keberhasilan belajar siswa melalui penggunaan sumber belajar berbasis Information Technologi apakah mencapai KKM atau tidak. Hal ini bisa dilihat dari hasil tugas-tugas siswa yang sudah dikerjakan. Berdasarkan paparan Nana Sudjana dalam bukunya bahwa hasil belajar siswa pada hakikatnya adalah perubahan tingkah laku sebagai hasil belajar dalam pengertian yang lebih luas mencakup bidang kognitif, afektif, dan psikomotorik (Sudjana 2010).

Maksud pemberian tugas-tugas oleh guru juga untuk mengetahui sejauh mana pengetahuan kognitif siswa dalam menyerap materi dari guru di Madrasah. Dimyati dan 
Mudjiono menyebutkan hasil belajar merupakan hasil dari suatu interaksi tindak belajar dan tindak mengajar. Dari sisi guru, tindak mengajar diakhiri dengan proses evaluasi hasil belajar. Dari sisi siswa, hasil belajar merupakan berakhirnya pengajaran dari puncak proses belajar (Dimyati \& Mudjiono 2006).

Penggunaan sumber belajar yang telah digunakan tentu memiliki tujuan spesifik yaitu meningkatkan pemahaman siswa dalam proses pembelajaran IPS di MTs Nuris. Hal ini berkaitan dengan teori yang dikemukakan oleh Bruce Joyce menyebutkan tujuan IPS ada 3, yaitu Humanistic education. Diharapkan IPS mampu membentuk anak didik untuk memahami segala pengalamannya serta diharapkan lebih mengerti tentang arti kehidupan ini, citizenship education. Setiap anak didik harus dipersiapkan untuk mampu berpartisipasi secara efektif di dalam dinamika kehidupan masyarakatnya. masyarakat diliputi segala aktivitas yang menyandarkan setiap warganegara untuk bekerja secara benar dan penuh tanggungjwab demi kemajuannya,dan intellectual education. Tiap anak didik ingin memperoleh cara dan sarana untuk mengadakan analisis terhadap gagasan-gagasan serta mengadakan pemecahan masalah seperti yang telah dikembangkan oleh ahli-ahli ilmu sosial. Bersamaan dengan pertumbuhan kemamapuannya, anak didik seharusnya belajar untuk menjawab sebanyak mungkin pertanyaan serta menguji data secara kritis dalam berbagai situasi social (Endayani 2017).

\section{Kesimpulan}

Penggunaan sumber belajar berbasis information technologi dalam meningkatkan hasil belajar IPS di MTs Nurul Islam Silo yaitu dalam tema "Perdagangan antar daerah atau antar pulau dan perdagangan internasional" sumber belajar yang digunakan selain dari buku siswa dalam bentuk ebook guru juga menggunakan artikel sebagai sumber belajar dalam materi tersebut. Guru mengarahkan siswa untuk browsing mencari artikel-artikel lain sesuai dengan materi menggunakan nootbook yang dibawa sendiri dan fasilitas wifi yang disediakan disekolah. Sedangkan untuk tema "Mengenal Negara-negara ASEAN (Letak astronomis, geografis, geologis negara-negara ASEAN)" guru menggunakan sumber belajar selain buku siswa juga menayangkan video tentang keadaan alam Negara-Negara ASEAN. Kedua tema di atas ada perubahan penggunaan sumber belajar berbeda yang digunakan oleh guru dalam pembelajaran IPS. Pengembangan sumber belajar yang digunakan dalam pembelajaran IPS dengan teknologi, seperti penggunaan ebook buku siswa kelas VIII, artikel-artikel yang diperoleh dari browshing, video dari youtube, power point, gambar, dan mengaitkan dengan fenomena yang ada disekitar. 
Hasil belajar siswa dengan menggunakan sumber belajar berbasis information technologi dalam Meningkatkan Hasil Belajar pada Mata Pelajaran IPS di MTs Nurul Islam Silo guru memberikan tugas mandiri seperti mengerjakan soal yang ada di buku siswa dan tugas kelompok, seperti melakukan analisis masalah yang dihadapi nelayan. Pemberian tugas-tugas oleh guru juga untuk mengetahui sejauh mana pengetahuan kognitif siswa dalam menyerap materi dari guru di Madrasah. Nilai siswa yang menjadi tolak ukur dalam menentukan keberhasilan siswa melalui penggunaan sumber belajar berbasis information technologi. Perolehan hasil belajar tersebut sangat beragam tetapi hasil nilai yang diperoleh. mengalami peningkatan.

\section{Referensi}

Dimyati \& Mudjiono. 2006. Belajar Dan Pembelajaran. Bandung: Alfabeta.

Endayani, Henni. 2017. "Pengembangan Materi Ajar Ilmu Pengetahuan Sosial." Ijtimaiyah 1. Musfiqom. 2012. Pengembangan Media Dan Sumber Pembelajaran. Yogyakarta: Prestasi Pustaka Raya.

Pane, Aprida, and Muhammad Darwis Dasopang. 2017. "Belajar Dan Pembelajaran." FITRAH:Jurnal Kajian Ilmu-Ilmu Keislaman 3(2):333. doi: 10.24952/fitrah.v3i2.945.

Rohani, Ahmad. 1997. Media Instruksional Edukatif. Jakarta: CV Rineka Cipta.

Rusman. 2012. Belajar Dan Pembelajaran Berbasis Komputer. Bandung: Alfabeta.

Sudjana, Nana. 2010. Penilaian Hasil Proses Belajar Mengajar. Bandung: PT. Ramaja Rosdakarya.

Umam, Ahmad Khoirul. 2018. "Pengaruh Pemanfaatan Sumber Belajar Terhadap Hasil Belajar Siswa Pada Mata Pelajaran Sejarah Kebudayaan Islam Kelas VIII Di MTs Negeri 2 Kota Blitar." IAIN Tuluagung.

Warsita, Bambang. 2009. Teknologi Pembelajaran Landasan \& Aplikasi. Jakarta: Rineka Cipta. 